\title{
Kloramfenikol øyedråper i behandling av maxillarsinusittliknende plager
}

\begin{abstract}
BAKGRUNN Egne kliniske erfaringer i allmennpraksis de siste 15 årene har vist at kloramfenikol øyedråper kan ha gunstig effekt på mange pasienter med akutte maxillarsinusittliknende plager. Vi ønsket å gjennomføre en pilotstudie for å teste holdbarheten av denne observasjonen.
\end{abstract}

MATERIALE OG METODE Behandling med kloramfenikol øyedråper eller systemisk peroral antibiotikabehandling ble testet ut på pasienter med akutte maxillarsinusittliknende plager. Pasientene ble randomisert til to grupper: Én fikk systemisk peroral antibiotika, den andre fikk kloramfenikol øyedråper.

RESULTATER 33 pasienter ble inkludert i studien - 27 kvinner og seks menn - herav 15 til tablettgruppen og 18 til kloramfenikolgruppen. De som ble behandlet med tabletter, opplevde tydelig bedring etter gjennomsnittlig 5,0 dager, mens de som ble behandlet med kloramfenikol øyedråper, opplevde bedring etter 3,7 dager ( $p=0,047) .14$ av pasientene i kloramfenikolgruppen beskrev bedring i løpet av tre dager, mens dette kun gjaldt fem pasienter i tablettgruppen.

FORTOLKNING Behandling med kloramfenikol øyedråper ser ut til å kunne være et alternativ for noen pasienter med akutte maxillarsinusittliknende symptomer. I pilotstudien var behandlingstiden før bedring av symptomene kortere hos pasienter som fikk øyedråper enn hos pasienter som fikk systemisk peroral antibiotika. Disse lovende resultatene gir grunn til å utføre større studier.

Sinusitt er et vanlig problem i allmennpraksis. $1-5 \%$ av den voksne befolkning i Europa rammes årlig av sinusitt, og $0,5-2 \%$ av alle pasienter med forkjølelsessymptomer utvikler symptomer på en akutt bakteriell sinusitt $(1,2)$. Infeksjonen kan være lokalisert i både frontal-, etmoidal- og maxillarsinus. Bildefremstilling av sinusitter kan gjøres ved CT- eller ultralydundersøkelse $(3,4)$. I vanlig allmennpraksis utføres ikke bildediagnostikk før behandling igangsettes, da diagnosen stilles klinisk. Bakteriefloraen som finnes ved maxillarsinusitt i Norge er primært Streptococcus pneumoniae og Haemophilus influenzae (5). For peroral antibiotikabehandling av akutt sinusitt i Norge har standard til nå vært fenoksymetylpenicillin 0,66-1,3 g × 3-4 i 7-10 dager (6).

En stadig økende resistensutvikling hos S. pneumoniae overfor fenoksymetylpenicillin og makrolider har ført til økende bruk av nye og mer bredspektrede antibiotika. Flere studier de senere årene gir ingen sikre holdepunkter for at peroral antibiotika gir noen vesentlig gevinst $i$ behandlingen av akutt sinusitt, da de fleste blir friske også uten slik behandling (7-9). I studier med brukt referansestandard (f.eks. CT-undersøkelse av bihulene) er det funnet forskjeller i effekt mellom antibiotikabehandling og placebo. Dette er ikke funnet i studier med bare kliniske endepunkter (8).

I en dobbelblindet, randomisert, placebokontrollert studie sammenliknet man behand- lingseffekten av peroral amoksicillin med budesonid nesespray (10). Konklusjonen var at antibiotika eller budesonid verken alene eller i kombinasjon er effektive i behandlingen av akutt maxillarsinusitt. Det er ikke enighet om fortolkningen av disse resultatene (11), og peroral antibiotikabehandling av akutt sinusitt i allmennpraksis er blitt kritisert som overbehandling (12).

Egne kliniske erfaringer med pasienter (IRN) i allmennpraksis de siste 15 årene har vist at bruk av kloramfenikol øyedråper kan ha gunstig effekt på pasienter med akutte maxillarsinusittliknende symptomer. Vi ønsket å gjennomføre en pilotstudie for å teste holdbarheten av denne observasjonen. Hensikten var å sammenlikne behandlingstid før pasientopplevd bedring, pasienttilfredshet og bivirkninger ved bruk av henholdsvis kloramfenikol øyedråper applisert i conjunctiva og peroral antibiotikabehandling hos pasienter med akutte maxillarsinusittliknende symptomer.

\section{Materiale og metode}

Alle fastleger i Møre og Romsdal (totalt ca. 220 leger) ble høsten 2008 kontaktet per brev og invitert til å delta i prosjektet. For å eliminere pollensesongen ble perioden november/ desember valgt. Fastlegene ble bedt om å bruke et rapporteringsskjema (auditskjema) (13) og registrere alle pasienter med sinusitt i det valgte tidsrommet, også de som ikke oppfylte inklusjonskriteriene. Pasientene måtte

\author{
Iris Relling Nielsen \\ i.relling@mimer.no \\ Vatne legekontor \\ Vatne \\ Arnfinn Seim \\ Niels Bentzen \\ Medisinsk Teknisk Forskningssenter \\ Institutt for samfunnsmedisin \\ Norges teknisk-naturvitenskapelige universitet
}

IL Engelsk oversettelse på www.tidsskriftet.no > Se også side 2117

\section{HOVEDBUDSKAP}

Det ser ut som om utvalgte pasienter med akutte maxillarsinusittliknende symptomer kan behandles effektivt med kloramfenikol øyedråper

I pilotstudien var bivirkningene ved bruk av kloramfenikol øyedråper få, pasienttilfredsheten god og behandlingstiden kortere enn med peroral antibiotikabehandling

Resultatene gir grunn til å utføre større studier 
oppfylle minimum to av følgende inklusjonskriterier (14):

- Purulent sekret i nese/bakre svelg

- Ømhet/perkusjonssmerte over sinus maxillaris

- Smerte i overkjeven ved fremoverbøying

- Tannsmerter ved gange eller tygging

- Tofaset sykdomsforløp

Eksklusjonskriteriene var kronisk sinusitt, allergi overfor kloramfenikol, alder under 18 år og pasienter der en kunne forvente dårlig etterlevelse, uten at dette ble spesifisert nærmere.

Fastlegene ble bedt om å diagnostisere pasientene med maxillarsinusitt klinisk uten å benytte seg av supplerende diagnostiske metoder som CT- eller ultralydundersøkelse. Dette for at diagnostiseringen skulle være mest mulig slik som i vanlig klinisk allmennpraksis.

For hver pasient som ble inkludert i pilotstudien, måtte fastlegen som behandlet vedkommende ta telefonisk kontakt med forsker (IRN) for fortløpende randomisering til tablettgruppe eller kloramfenikolgruppe. De pasientene som ble randomisert til kloramfenikolgruppen, fikk utskrevet resept på kloramfenikol øyedråper som skulle dryppes i begge øyne 8-10 ganger daglig i 2-4 dager eller inntil symptomene forsvant. Pasienter som ble randomisert til tablettgruppen, fikk et antibiotikum etter legens eget valg og dosering.

Alle inkluderte pasienter fikk utdelt et pasientspørreskjema som skulle besvares etter endt behandling og returneres til behandlende lege. Her skulle de angi antall dager før tydelig bedring ble oppnådd (hovedutfall). Dersom pasienten ikke opplevde bedring, ble dette angitt som ti dager før bedring inntraff, da dette vanligvis er øvre grense for antall dager med peroral antibiotikabehandling. Det ble også spurt om bivirkninger av behandlingen. Pasientene i kloramfenikolgruppen ble i tillegg spurt om hvorvidt de hadde dryppet som foreskrevet og om hvilken behandling de ville foretrekke ved en eventuell senere maxillarsinusittliknende episode. Legene sendte alle innleverte pasientspørreskjemaer sammen med utfylt rapporteringsskjema tilbake til forsker (IRN).

Antall dager før pasienten merket tydelig bedring ble satt som hovedutfall. For styrkeberegningen ble målet for en klinisk signifikant forskjell mellom tradisjonell behandling (antibiotika) og testbehandling (kloramfenikol øyedråper) satt til $20 \%$ reduksjon i antall dager før opplevd bedring. Dette tilsvarer omtrent én behandlingsdag. Vi forutsatte et standardavvik (SD) på to dager og et signifikansnivå på $5 \%(\mathrm{p}=0,05) \mathrm{i}$ de to behandlingsgruppene. I en tosidig test beregnes da en teststyrke på $80 \%$ med 60 pasienter i hver gruppe. Teststyrken blir tilnærmet $90 \%$ med 80 pasienter i hver gruppe. Beregningene er basert på et antatt gjennomsnitt på fem dager før tydelig bedring i tablettgruppen og tilsvarende fire dager i kloramfenikolgruppen. Hvis spredningen i gruppene ble mindre (lavere standardavvik), ville det være tilstrekkelig med færre pasienter i hver gruppe.

Statistikkprogrammet SPSS ble benyttet for statistisk bearbeiding. Ved sammenlikning av gjennomsnittlig antall dager før pasientopplevd bedring $i$ de to gruppene ble Mann-Whitneys U-test benyttet.

Pilotstudien er godkjent av regional komité for medisinsk forskningsetikk Midt-Norge, Norsk samfunnsvitenskapelig datatjeneste (NSD) og Statens legemiddelverk, og den er registrert i EudraCT (European Clinical Trial Database) i 2008.

\section{Resultater}

22 fastleger besvarte henvendelsen. Totalt 38 pasienter ble randomisert til pilotstudien. Tre av pasientene i tablettgruppen trakk seg fra studien uten nærmere begrunnelse. En av pasientene i kloramfenikolgruppen måtte avbryte pga. allergisk reaksjon, og en pasient fylte ikke ut skjemaet pga. språkvansker. 33 pasienter inngikk i pilotstudien: 27 kvinner og seks menn. 18 av disse var randomisert til kloramfenikolgruppen og 15 til tablettgruppen. Aldersspredningen $\mathrm{i}$ de to gruppene var tilnærmet lik: 22-61 år i kloramfenikolgruppen og 27-67 år i antibiotikagruppen.

Kun tre av de inkluderte 33 pasientene oppfylte alle fem inklusjonskriteriene: purulent sekret i nese/bakre svelg, ømhet/perkusjonssmerte over sinus maxillaris, smerte i overkjeven ved fremoverbøying, tannsmerter ved gange eller tygging samt tofaset sykdomsforløp. Åtte pasienter oppfylte to kriterier, ti pasienter oppfylte tre og 12 pasienter oppfylte fire. I hver av gruppene ble det registrert totalt tre pasienter som fikk tilleggsbehandling i form av nesespray eller saltvannsskylling.

\section{Effekt}

Gjennomsnittlig antall dager før pasientopplevd tydelig bedring var 5,0 hos pasientene som var behandlet med antibiotika, mens de som ble behandlet med kloramfenikol opplevde tydelig bedring etter 3,7 dager $(p=0,047)$. Dette gir i gjennomsnitt 1,3 dager raskere bedring for pasientene i kloramfenikolgruppen enn for pasientene i tablettgruppen. Fordelingen på antall dager før egenopplevd tydelig bedring $\mathrm{i}$ de to gruppene fremgår av tabell 1 .

\section{Pasienttilfredshet}

Pasientene i kloramfenikolgruppen ble bedt om å svare på hvilken behandling de ville
Tabell 1 Antall pasienter med tydelig egenrapportert bedring, fordelt på behandlingsgruppe og dager etter behandlingsstart

\begin{tabular}{lcc}
$\begin{array}{l}\text { Dager etter } \\
\text { behandlings- } \\
\text { start }\end{array}$ & $\begin{array}{c}\text { Kloramfeni- } \\
\text { kolgruppe, } \\
\text { antall } \\
\text { rapport } \\
\text { bedring }\end{array}$ & $\begin{array}{c}\text { Tablett- } \\
\text { gruppe, } \\
\text { antall } \\
\text { rapportert } \\
\text { bedring }\end{array}$ \\
1 & 3 & 1 \\
2 & 9 & 2 \\
3 & 2 & 2 \\
4 & 0 & 4 \\
5 & 0 & 1 \\
6 & 0 & 1 \\
7 & 0 & 1 \\
10 eller & & 3 \\
ingen bedring & 4 & 15 \\
\hline Totalt & 18 & \\
\hline
\end{tabular}

foretrekke ved en eventuell senere liknende hendelse. 12 av dem ville ha foretrukket samme behandling, mens seks ville foretrekke peroral antibiotika eller annen behandling. Pasientene svarte også på hvorvidt de etterlevde rådet om drypping 8-10 ganger daglig. Kun én pasient anga å ha dryppet sjeldnere enn foreskrevet.

\section{Bivirkninger}

I kloramfenikolgruppen måtte én pasient avbryte pga. allergisk reaksjon i form av hodepine, kvalme og frysninger. Denne pasienten inngår ikke i resultatanalysen. To andre opplevde irritasjon i form av tørre øyne, men disse avbrøt ikke behandlingen. I tablettgruppen rapporterte seks pasienter $(43 \%)$ om bivirkninger $\mathrm{i}$ form av mageplager (diaré, obstipasjon, kvalme og anal kløe). Ingen av disse trakk seg fra studien.

\section{Diskusjon}

Så vidt vi kjenner til er behandling av maxillarsinusittliknende plager med kloramfenikol øyedråper ikke tidligere beskrevet. I denne pilotstudien, hvor peroral antibiotika ble sammenliknet med kloramfenikol øyedråper, svarte 14 av 18 pasienter i kloramfenikolgruppen $(78 \%)$ at de merket tydelig bedring etter tre dagers behandling, mens det tilsvarende tallet $\mathrm{i}$ gruppen for peroral antibiotikabehandling var fem av 15 (33\%). Pasientene i kloramfenikolgruppen registrerte i gjennomsnitt bedring 1,3 dager raskere enn pasientene i tablettgruppen.

Ideelt sett burde vi i denne pilotstudien ha sammenliknet behandling med kloramfeni- 
kol øyedråper med placebo. Pasienter som henvender seg til sin fastlege for sinusittliknende plager har imidlertid forventninger om «effektiv» behandling og rask virkning. Det ble derfor ikke laget placebogruppe eller gruppe for ingen behandling.

I vår studie ble det ikke innhentet opplysninger om hva slags type peroralt antibiotikum fastlegen valgte å forskrive. Det kan diskuteres hvorvidt et standardisert valg av antibiotikum ville kunne ha bidratt til et mer homogent sammenlikningsgrunnlag mellom gruppene. På den annen side bidro vår design til at behandlingen var mest mulig lik den som fastlegen ville ha valgt $i$ vanlig praksis.

Den totale oppfølgingstiden i studien var ti dager etter påbegynt behandling. Siden denne studien først og fremt er en pilotstudie for effekt, bivirkningsfrekvens og pasienttilfredshet, ble den ikke spesifikt designet for å se nærmere på eventuelt residiv av symptomer etter avsluttet behandling. I senere studier bør man ta høyde også for dette.

En nyere litteraturgjennomgang konkluderer med at antibiotika har begrenset virkning og bør ha liten plass i behandling av klinisk diagnostisert akutt sinusitt (15). Av denne grunn burde behandling med kloramfenikol øyedråper kanskje heller sammenliknes med saltvannsdråper applisert i conjunctiva eller ingen medikamentell behandling. Studier viser imidlertid at saltvannsnesespray ikke kommer bedre ut enn placebo ved behandling av akutte sinusittliknende plager (16).

Dersom våre resultater kan bekreftes $\mathrm{i}$ større studier, vil behandling med kloramfenikol øyedråper kunne bli et alternativ ved akutt maxillarsinusitt. Gevinster vil kunne være redusert behandlingstid og færre bivirkninger. Denne behandlingen vil likevel ikke være et alternativ for alle med slike plager. For mange vil saltvannsskylling eller ingen behandling fortsatt være aktuelt, mens systemisk antibiotikabehandling da kan forbeholdes pasienter som er syke med feber og redusert allmenntilstand som følge av sinusitten samt pasienter som er allergiske mot kloramfenikol.

I vår studie var det færre bivirkninger $\mathrm{i}$ kloramfenikolgruppen enn i tablettgruppen, noe som er en viktig gevinst. Det er en generell målsetting i allmennpraksis å minimere bruken av systemiske antibiotika, da dette både vil kunne redusere utviklingen av antibiotikaresistens og påføre færre pasienter bivirkninger $(17,18)$.

Mulige forklaringer på effekten av kloramfenikol øyedråper ved akutte maxillarsinusittliknende plager kan være at de hemmer bakterieveksten i nesekaviteten eller at de løser opp en mulig sekretpropp som hemmer drenasjen fra sinus. Normalisering av drenasjen kan være den direkte årsaken til en rask bedring, men man kan også tenke seg at den lokale virkningen på slimhinnen i nesen er avgjørende. I så fall kan kloramfenikol nesespray kanskje vise seg å være like virkningsfullt.

Denne pilotstudien har få deltakere, noe som gjør statistiske beregninger usikre. Det vil også være vanskelig å oppnå statistisk signifikante forskjeller mellom gruppene som sammenliknes. Våre resultater viser likevel signifikant raskere bedring ved behandling med kloramfenikol øyedråper sammenliknet med systemisk antibiotikabehandling. Studiens størrelse tilsier dog at det er grunn til å tolke resultatene med varsomhet, og resultatene bør etterprøves i en større randomisert studie. Siden behandling av sinusitt med kloramfenikol øyedråper innebærer et helt nytt prinsipp, burde det være av stor interesse å gå videre med nye studier. Om resultatene fra vår pilotstudie kan bekreftes, har man fått et effektivt og billig behandlingsalternativ med lite bivirkninger for pasienter med akutte maxillarsinusittliknende symptomer.

\section{Iris Relling Nielsen (f. 1956)}

er spesialist i allmennmedisin.

Forfatter har fylt ut ICMJE-skjemaet og oppgir ingen interessekonflikter.

\section{Arnfinn Seim (f. 1956)}

er spesialist i allmennmedisin og samfunnsmedisin.

Forfatter har fylt ut ICMJE-skjemaet og oppgir ingen interessekonflikter.

\section{Niels Bentzen (f. 1944)}

er spesialist i allmennmedisin

Forfatter har fylt ut ICMJE-skjemaet og oppgir ingen interessekonflikter.
Litteratur

1. Ah-See K. Sinusitis (acute). Clin Evid (Online) 2011 E-publisert 21.12.

2. Desrosiers M, Frenkiel S, Hamid QA et al. Acute bacterial sinusitis in adults: management in the primary care setting. J Otolaryngol 2002; 31 (suppl 2): 2S2-14

3. Lindbæk M, Johnsen UL, Kaastad $\mathrm{E}$ et al. CT findings in general practice patients with suspected acute sinusitis. Acta Radiol 1996; 37: 708-13.

4. Puhakka T. Heikkinen T. Mäkelä MJ et al. Validity of ultrasonography in diagnosis of acute maxillary sinusitis. Arch Otolaryngol Head Neck Surg 2000; 126: $1482-6$

5. Lindbæk M, Melby KK, Schøyen R et al. Bacteriological findings in nasopharynx specimens from patients with a clinical diagnosis of acute sinusitis. Scand J Prim Health Care 2001; 19: 126-30.

6. Helsedirektoratet. Nasjonale faglige retningslinjer for antibiotikabruk i primærhelsetjenesten. www.helsebiblioteket.no/microsite/ antibiotikaretningslinjer (4.3.2013)

7. Hickner JM, Bartlett JG, Besser RE et al. Principles of appropriate antibiotic use for acute rhino sinusitis in adults: background. Ann Emerg Med 2001: 37: 703-10.

8. Ahovuo-Saloranta A, Borisenko OV, Kovanen N et al. Antibiotics for acute maxillary sinusitis. Cochrane Database Syst Rev 2008; 2: CD000243.

9. Young J, De Sutter A, Merenstein D et al. Antibiotics for adults with clinically diagnosed acute rhinosinusitis: a meta-analysis of individual patient data. Lancet 2008; 371: 908-14.

10. Williamson IG, Rumsby K, Benge $\mathrm{S}$ et al. Antibiotics and topical nasal steroid for treatment of acute maxillary sinusitis: a randomized controlled trial. JAMA 2007; 298: 2487-96.

11. Lindbæk M. Acute sinusitis - to treat or not to treat? JAMA 2007: 298: 2543-4.

12. Lindbæk M, Butler CC. Antibiotics for sinusitis-like symptoms in primary care. Lancet 2008; 371 : $874-6$

13. Bjerrum L, Munck A, Gahrn-Hansen B et al. Health Alliance for Prudent Prescribing, Yield and Use of Antimicrobial Drugs in the treatment of respiratory tract infections (HAPPY AUDIT). BMC Fam Pract 2010; 11: 29.

14. NEL (Norsk Elektronisk Legehåndbok) http://legehandboka.no/ore-nese-hals/ tilstander-og-sykdommer/nese-og-bihuler/ bihulebetennelse-akutt-3506.html - IDOEECA (12.11.2012).

15. Lemiengre MB, van Driel ML, Merenstein D et al. Antibiotics for clinically diagnosed acute rhinosinusitis in adults. Cochrane Database Syst Rev 2012; 10: CD006089

16. Kassel JC, King D, Spurling GK. Saline nasal irrigation for acute upper respiratory tract infections. Cochrane Database Syst Rev 2010; 3: CD006821.

17. Bergogne-Bérézin E. Treatment and prevention of antibiotic associated diarrhea. Int $J$ Antimicrob Agents 2000; 16: 521-6.

18. Pirotta MV, Garland SM. Genital Candida species detected in samples from women in Melbourne. Australia, before and after treatment with antibiotics. J Clin Microbiol 2006; 44: 3213-7.

Mottatt 22.8. 2011, første revisjon innsendt 27.9. 2012, godkjent 14.8. 2013. Redaktør Are Brean. 